Dorota SKOWROŃSKA ${ }^{1}$

Ateneum-Szkoła Wyższa w Gdańsku

\title{
Report on the Language Show, London, 9-11 November 2018
}

The Language Show is an annual event for linguists, language teachers, translators, and interpreters held in London. On 9-11 November 2018, the Language Show hosted three days of seminars, talks, presentations, and workshops. Dozens of exhibitors presented their institutions (among others, British Council, Chartered Institute of Linguists, Department for Education, European Union, Goethe-Institut, Instituto Cervantes), universities (University of London, University of Oxford, Trinity College London, University of Leeds), and products (SDL Trados, Testronic Labs, uTalk, Yabla). The Language Show offered free-ofcharge admission to all events, and online ticket reservation was available.

The great hall of the Olympia Exhibition Centre was divided into separate sectors. The centre was occupied by exhibitors' stands offering information and product samples. Visitors had the opportunity to talk to the staff of the British Council promoting the most sought after English language exams IELTS Cambridge Assessment English, various language teaching institutions and schools, tech companies providing smart solutions for learners, companies searching for teachers willing to teach English abroad, and publishers of language coursebooks and materials.

Three seminar rooms provided the space for presentations and seminars on language teaching (concerning mostly popular European languages), technology augmenting the work of teachers and translators, and challenges facing the teaching and translation industries. Four presentations seemed particularly interesting: "Linguistics in everyday life", "Introduction to CAT tools", "Bringing language alive through creative projects" and "Quick wins with technology in the languages classroom".

"Linguistics in everyday life", presented by Doctor Rebecca Mitchell, lecturer of the University of Cambridge, was centred on various aspects of linguistics and their application in everyday life and work. Dr Mitchell

https://orcid.org/0000-0002-7701-9653. 
prepared a slide show peppered with entertaining cat images (which, as she explained, helps the audience focus on the discussed topics to a greater extent than in case of a standard, kitten-less presentation), with each slide showing how linguistic knowledge (in the area of psycholinguistics, sociolinguistics, morphology, or phonology) can enhance a deeper understanding of individual or social issues. The presentation also pointed possible career paths for linguists who can be employed by non-academic businesses creating speech synthesisers, text-to-speech software, offering elocution and pronunciation tutoring, and even government services working on speech analysis of alleged or suspected perpetrators of criminal and terroristic acts.

The presentation titled "Introduction to CAT tools" was led by Daniela Ford and Kari Koonin, two practising translators with decades of experience in professional, non-academic translations. The presenters analysed two most popular (and probably most expensive) CAT programs, listed their strengths and weaknesses and offered practical advice on how to choose a program most suitable for a particular translator. The presenters also listed practical applications of CAT tools in freelance work and the reasons to consider before investing in such programs.

"Bringing language alive through creative projects" was presented by Nadine Chadier, a French teacher employed at St Jérôme Church of England Bilingual Primary School in Harrow. Ms Chadier showed how the school staff utilises everyday school activities to drill pupils in natural responses and to expand their lexical and grammatical skills. The presenter encouraged to the teachers in the audience to create films with pupils giving short talks in French (or other languages taught at school) on familiar topics, to insert elements of foreign languages into pupils' interactions during breaks, school trips, and other activities. Ms Chadier stressed the importance of language and cultural immersion experienced by pupils in and out of the classroom.

"Quick wins with technology in the languages classroom" proved to be, in my opinion, the most valuable and exciting presentation of the Language Show. Joe Dale, an independent language consultant, cooperating with various institutions and businesses engaged in language teaching, presented programs and mobile applications which can be utilised to create audio and video recordings for the classroom. Most of the applications and programs are available free of charge: Talkee, Padlet, Clips, Adobe Spark, TextingStory, and Super Hero Comic Book Maker. Other software such as Apple Keynotes is a standard program compatible with MacBooks and iPads and may be used in teachers' everyday work. All the above-mentioned software can be used not only by language school teachers or public school teachers but also by academic teachers and lecturers who 
would like to make their lectures and courses more attractive to students. Information boards with $\mathrm{QR}$ codes offering access to online content may prove more successful in encouraging students to join language projects and research groups than traditional advertisements. Since younger generations prefer interactive, online content, such applications may provide them with easier access to necessary information. Joe Dale offers training to institutions worldwide, and it would be immensely beneficial to invite him to present his idea in our institutions in Poland.

"Language Tasters" were an essential, and immensely entertaining, element of the Language Show. These are thirty-minute presentations of several languages, which included this year Polish, Mandarin, French, Swahili, and Welsh. During the tasters, participants had the chance to hear about grammatical and phonological features of the languages and learn several useful phrases such as greetings and polite forms of address. The tasters also proved an opportunity to experience various teaching methods used by their presenters: the Mandarin teacher connected phonological features of this slightly exotic language for the Europeans in the audience with a traditional children's song. After each taster, the presenters answered more detailed questions about their languages and offered advice on choosing language courses and learning methods.

Visiting the Language Show is a boost of energy and new ideas to teachers wanting to make their teaching more attractive and to encourage students to participate in language and research projects. https://languageshowlive.co.uk 
